\title{
Local representative democracy and protest politics: the case of the Five-star Movement
}

\author{
Author: Davide Vampa \\ Affiliation: European University Institute \\ Address: (permanent) Via Dei Roccettini 50014 San Domenico di Fiesole (FI) - Italy \\ (current) Flat 583 Palmerston Road, N22 8QS, London, UK \\ Phone Numbers: 00393459228161 or 00447760458564 \\ Email: davide.vampa@eui.eu
}

Biographical note: Davide Vampa teaches Quantitative Methods at the London School of Economics and at the School of Oriental and African Studies (University of London). He is a researcher at the European University Institute where he is completing a $\mathrm{PhD}$ on the territorialisation of social policy in Western Europe (with a focus on Italy, Spain and Great Britain). He has also worked and published on political parties and elections in Italy and Western Europe. 
Abstract. In recent years, protest politics has become a relevant phenomenon in various European countries. Italy has witnessed the rise of the Five-star Movement (M5S), an antiestablishment party which, at the 2013 general election, obtained one fourth of the total votes. However, the story of this 'party-movement' started at the local level, as a civic network aimed at changing administrative practices in municipal government. By using an original dataset on representation in 671 Italian municipalities in the period from 2010 to 2014, this article aims to explain not only the sub-national political success of the M5S but also the challenges and contradictions that a newly formed movement faces in multi-level electoral arenas.

Keywords: Five-star Movement, local politics, protest politics, political representation, Italy

In recent years, especially since 2008 when the economic crisis began, the political landscapes of a number of European countries have been dramatically changed due to the emergence and growth of parties and movements that openly challenge the "political establishment' (Matthijs, 2014). The Italian political system in particular has undergone radical transformation. Indeed, the equilibrium that emerged and was consolidated during the 1990s has been substantially altered and the main cause of this new electoral earthquake has been the rise of the Five-star Movement (M5S), an anti-establishment party that cannot be easily located on the traditional left-right spectrum. As a result of the Movement's success, the Italian party system has ceased to be a system based on the competition of two (more-orless cohesive) centre-left and centre-right coalitions and has become a 'multi-polar' or ‘tripolar' system (Ventura, 2013).

Hartleb (2013) has defined the M5S as an 'anti-elitist cyber party' to underline the increasing importance of the new social media as arenas of political interaction and participation. At the same time, while emphasising the importance of the resources offered by the internet, Bordignon and Ceccarini (2013: 427) have also pointed to the fact that 'the mobilisation stimulated and encouraged by the M5S does not just take place online but also offline in local communities' (italics added). Indeed, the M5S initially emerged and grew strong at the municipal level as a horizontal network of local associations promoting the creation of independent and 'certified' citizens' lists (Natale, 2014), which campaigned on local issues (most notably, the privatisation of council-owned water supplies and the construction of incinerators for garbage disposal) and in turn received publicity and support from the official website of the comedian Beppe Grillo (Turner 2013, 215). As emphasised by Bartlett et al. (2013: 19): 
Social media is only part of the story. Grillo's success also demonstrates that communicating and organising through the internet is not a substitute for realworld political activism, rather something that can facilitate it. The M5S also acts locally [italics added], and its strength appears to be the way it combines online and offline activism effectively. The 'meet-ups', made up of people who gather and meet offline in their local communities every week or so, are critical for the movement's success: they often drive the debates and discussions, for example reviewing the extent to which city councils or regional governments are performing.

In 2010 the Five Star Movement achieved its first significant successes ${ }^{1}$ in local elections with a platform that was 'apolitical' and particularly focused on local issues (De Lucia, 2012). At the beginning, 'Grillo's activity was limited to using his abilities and his notoriety to give voice ... to local protests and initiatives of mobilisation "from below" (Biorcio 2014: 38). As highlighted by Lanzone and Tronconi (2015), local 'meet-ups' were created in the localities and were independent of each other, with no central control or coordination.

Only at a second stage did Beppe Grillo and co-founder of the Movement, Gianroberto Casaleggio, decide to launch a national campaign - a campaign that led to unexpected success at the 2013 general election: the Movement won 25\% of the total vote. This means that since the late 2000s the M5S has undergone a process of politicisation, nationalisation and organisational development that has made it something significantly different from a loose network of local groups and associations and more similar to a protest or anti-system party. Yet any study that aims fully to understand the factors that have favoured the emergence and success of the M5S should not neglect the local dimension of politics. Indeed, such a dimension can also be called the 'political ecology' (Carty and Eagles, 1998) in which a party (or movement) has its organisational roots and its activists mainly participate.

The aim of this paper is therefore to understand in which local contexts the M5S has managed to achieve its greatest successes, particularly in terms of institutional representation. Generally, studies that explain the emergence of new political movements tend to focus on their national success (Conti and Memoli, 2015) and neglect their local origins and the interaction between different territorial levels of electoral competition. A recent, comprehensive book on the M5S edited by Tronconi (2015) pays attention to the local origins of the Movement. It emphasises that the network of local groups on which, at least initially, 
the strength of the M5S was based, has affected its more recent organisational development and has created various problems of coordination and communication across different territorial levels (lack of 'vertical' coordination). Starting from this premise, this article shows empirically that there is considerable variation in the strength of M5S local representation and seeks to explain such variation by testing, quantitatively, a set of hypotheses related to the political and socio-economic sub-national context. Additionally, it is suggested that diverging electoral successes in the local and national arenas may produce contradictions in the nature of a newly formed movement and eventually lead to internal tensions (and even splits) between grassroots activists and the national leadership.

The next section provides a general introduction to the analysis of multi-level party politics. After a brief description of the voting system used to elect municipal administrations in Italy, a set of hypotheses explaining variation in the strength of M5S local representation is presented and tested using descriptive statistics and a multiple linear regression model. The conclusions are preceded by an assessment of the link between local and national successes of the Movement and by a brief analysis of more recent electoral results (the 2015 local elections), which were not included in the original dataset.

\section{Territorial politics and (old and new) political parties: the increasing importance of the local arena}

Studies of the 'nationalisation of politcs' (Caramani, 2004) have suggested that since the emergence of national political parties in the late $19^{\text {th }}$ century, a process of territorial standardisation of electoral politics has occurred in advanced democracies. This may have been the result, in any specific case, of a bottom-up process of national aggregation of once locally focused political forces or else of a top-down process of increasing penetration of central political actors into peripheral and local contexts. This process was also accompanied by increasing institutional centralisation with the strengthening of central government vis-àvis local and regional authorities (Bartolini 2004, 2005). Therefore, classic studies of party politics were mainly concerned with the national dimension of political competition, since they were based on the assumption that the local dimension largely reflected (or was subordinated to) state-wide party dynamics. This approach is commonly called 'methodological nationalism' (Jeffrey, 2008; Jeffrey and Wincott, 2010; Amelina et al., 2012), which maintains that the national state or national society is 'the natural social and political form of the modern world' (Wimmer and Glick Schiller, 2002: 302). 
However, at the turn of the $20^{\text {th }}$ century many studies suggested that the process of nationalisation and territorial standardisation of politics had started to reverse - not only because of the emergence and strengthening of so-called 'regionalist parties' (De Winter and Türsan, 1998) or local lists (Reiser and Holtmann, 2008), but also because of processes of decentralisation of political institutions. For instance, Loughlin (2001) and John (2001) have underlined the increasing importance of the regional and local levels of administration in European democratic systems. Additionally, focusing on the regional dimension, Hooghe et al. (2010) have shown empirically that an important process of decentralisation has occurred in most European and non-European countries over the last thirty years. Italy has not been an exception among western European countries and substantial (fiscal and policy-making) powers have been devolved to the regions (regioni) and municipalities (comuni) (Palermo and Wilson, 2014). The introduction of a new voting system for the municipalities in the early 1990s substantially increased the prestige and the political strength of directly elected mayors (Baldini, 2002).

Given the significant territorial reconfiguration of governance that has occurred in many advanced democracies (including Italy), scholars have devoted increasing attention to the relationship between central, regional and local levels of party politics. The 'territorialisation' of political parties has a number of dimensions. These include: the adoption of stronger territorial party identities and rhetoric; calls for greater organisational and programmatic differentiation from the centre, and the development of alternative constitutional goals. Since power and authority no longer rest in one single place, different organisational units within parties possess different powers and autonomous functions (Hepburn, 2010). Therefore, it is not surprising that many parties have developed new 'stratarchical' organisational structures (Carty, 2004; Katz and Mair, 2009). According to Katz and Mair (2009: 761), 'stratarchical adaptive strategies' may 'be pursued by national party leaders seeking to maintain local organisations, both for their utility in campaigns and to avoid the public perception of decay, but at the same time to free themselves of constraints imposed by those local organizations'. Other scholars have instead pointed to the 'federalisation' of party organisations, something that indicates the increasing influence exerted by regional and local party organisations on national political strategies (Detterbeck, 2005).

The existence of local and regional political institutions and the evolution of party organisations towards a more complex model of inter-level relations make the study of local 
politics increasingly important if we want to assess the evolution of representative democracy. More specifically, the study of the dynamics existing in local representative institutions may provide additional information on the organisation, political orientation and strategies of old and new parties, thus complementing nationally-focused studies. In recent years, new research has been devoted to the study of local elections and partisanship at the municipal level: see, for instance, Aars and Ringkjøb (2005) or Ennser-Jedenastik and Hansen (2013).

In a multi-level system, the control of local government and local representation may be very important for the consolidation and further strengthening of emerging parties. Particularly in the case of parties that do not participate in national government, local administration may become an alternative source of political strength. Indeed, the control of municipal offices may favour 'challenger parties' (Hino, 2012) in the achievement of two other important objectives: influence on policy and vote maximization (Müller and Strøm, 1999) not just in the local but also in the national arena. Generally, it can be argued that, due to the scarcity of political spoils available in the national arena, where mainstream parties often collude to limit the role played by challengers (Katz and Mair, 1995), some parties may benefit from the existence of 'spill-over' effects coming from lower levels of government, where political competition may be more open. Their local success may therefore pave the way for further success in regional and national elections and break the national oligopoly of mainstream parties.

This is why this article focuses on the local dimension, which may help us to understand better the nature of a challenger party. At the same time, I suggest that the local arena should not just be considered as an 'opportunity' for emerging parties or movements but also as a 'challenge' and a source of tensions between local and national representatives and leaders. This is particularly true in the case of political forces that are unable to build an integrated organisational structure after they have achieved considerable success at the national level.

\section{The voting system in Italian municipalities}

Before moving to the main hypotheses of this study and to their testing in the empirical analysis, a brief introduction to the voting system used in Italian municipalities is now presented. Since the electoral reform of 1993, mayors in the Italian municipalities have been directly elected (Baldini, 2002) and the composition of municipal councils has been 
determined through a mixed proportional-majoritarian system. Indeed, the list(s) supporting the winning candidate for mayor obtain(s) a 'majority bonus' (roughly around $60 \%$ of the seats), while the remaining seats are allocated proportionally among the losing lists. Yet, whereas in municipalities with less than 15,000 inhabitants the majority bonus is allocated regardless of the share of votes obtained by the winning candidate, in the other municipalities a two-round election is in place: if no candidate obtains more than $50 \%$ of the vote, then two weeks later a second election round involving the two strongest candidates takes place. Additionally, in municipalities with more than 15,000 inhabitants, parties and local movements may form autonomous lists in the first round and then form alliances in the second round. In smaller municipalities, on the other hand, parties supporting the same candidate for mayor must from a single list. This latter point makes it more difficult to assess changes in the composition of representation in small municipalities (Pritoni, 2014: 385). For this reason, this study focuses on municipalities with more than 15,000 inhabitants.

\section{The M5S in the local arena: assessing and explaining variation in the strength of its local representation}

As mentioned in the first section of this article, there is substantial variation in the share of council seats won by the M5S in Italian municipalities (which is the dependent variable used here) from 2010 to 2014. Most of the data used for this study have been drawn from the official archive of the Italian Interior Ministry (http://elezionistorico.interno.it/), which contains data concerning the results of local, regional, national and European elections. Data for some municipalities in 'special status' regions (Sicily, Sardinia, Friuli-Venezia Giulia, Valle d'Aosta and Trentino-Alto Adige) are not available from the Interior Ministry archive and in those cases the data have been drawn from the online archives of the two main Italian newspapers, Corriere della Sera and la Repubblica. Overall, the dataset includes 671 municipalities. If a municipality had more than one election during the period from 2010 to 2014, the results of the most recent election have been included in the analysis.

The strength of M5S local representation has been measured by calculating the percentage of seats won in each municipal council. These percentages range from 0 to 62.5 , with a mean of 4.5. Therefore, variation seems to be quite high, as also indicated by the standard deviation (8.5), which is almost twice as large as the mean. Generally, from its first successes until the local elections in May 2014, the M5S obtained at least some representation in 43 per cent of the municipalities included in the sample. Yet the number of 
directly elected majors supported by the M5S is quite small (only 8 in the 671 municipalities included in the sample). The lack of variation in this latter variable does not allow us to perform a quantitative analysis (i.e. logistic regression) with a dichotomous dependent variable (M5S mayor: yes/no). For this reason, this study focuses exclusively on the percentage of council seats won by the M5S.

As argued in the introduction, explaing the variation described above is an important theoretical and empirical exercise, since it may provide additional information on the nature of an important political actor, which, starting from the local level, has then managed to become the main challenger of established political actors nationally. Most of the hypotheses presented in this study are related to political factors.

First of all, it would be interesting to see whether the M5S has won a large share of representation in those municipalities that had previously experienced the emergence of socalled 'local lists'. Such lists can be seen as an indicator of new types of participation and representation, ones that fully transcend the mediation of party structures. According to Reiser and Holtmann (2008: 7) local lists 'understand themselves as protector of a harmonious factual political style' and 'perceive themselves as non-parties'. Moreover, using Holtman's (2008: 11) definition, local lists are focused on local jurisdictions and are solely locally organised. This means that they are interested exclusively in local issues and only have a town-based organisation, one not formally linked to any provincial, regional or national political organisation. Since its creation, the M5S has aimed to promote direct forms of citizen participation in the local arena without the mediation of traditional party structures. Therefore, it can be regarded as a natural development of the experience of local lists as promoters of 'partyless' local democracy. One may hypothesise that

H1. In the 2010-2014 period, the M5S was more successful, in terms of local representation, where the legacy of local lists was stronger, that is, in those municipalities where in the previous period (2005-2009) local lists won a larger share of seats.

Yet in the Italian context, one should distinguish between local lists that are fully external to mainstream party competition and those that are more inclined to establish alliances with traditional party lists. I call the former 'independent' local lists, whereas the latter can be defined as 'politicised' local lists or partisan lists 'in disguise'. Indeed, in a context of increasing de-politicisation of the local dimension, political parties may find it 
convenient to 'outsource' representation to lists that are not formally recognisable as 'partisan' but, in fact, contribute to the victory of coalitions in which political parties still play a significant (often dominant) role. Pritoni (2014: 390) calls this a 'blame avoidance' strategy, aimed at attracting the votes of those citizens who are increasingly sceptical of purely party-based politics. One may therefore expect that

H1a. The success of the MSS in the municipal arena has been more significant where the legacy of independent, rather than politicised, local lists has been stronger.

In the 671 municipalities considered in this article, independent local lists won, on average, 4.83 per cent of local seats during the 2005-2009 period. On the other hand, politicised local lists obtained 17.75 per cent of the municipal seats in the same period. Therefore, all together, local lists controlled, on average, more than one fifth of local council seats.

A second political factor that may explain variation in the success of the M5S is the failure of the previous administration to complete its mandate. This often happens as a consequence of corruption scandals, internal conflict resulting in the break-up of the ruling coalition, or resignation of the mayor. In the context of early elections, it may be easier for the M5S to point to the weaknesses of the previous administration and attract enough 'antielite' support to win significant representation in the local council or even win the municipal election. Therefore,

H2. The M5S share of local representatives is larger in those municipalities where early elections have been called.

In the dataset, almost 20 per cent of municipalities (132 out of 671) experienced early elections in the 2010-2014 period.

A third political factor refers to the political orientation of the previous municipal administration. The question is whether the success of the M5S changes depending on whether there is a centre-left or centre-right incumbent. In this way, it would be possible to assess whether the 'ideological' characteristics of the political context have favoured the strengthening of the M5S at the local level. Two alternative hypotheses may be formulated:

H3a. The M5S share of local representatives is larger in those municipalities previously governned by centre-right parties 
H3b. The M5S share of local representatives is larger in those municipalities previously governed by centre-left parties

In the period from 2005 to 2009,46 per cent of municipalities were ruled by centre-right parties, whereas 47.5 per cent of them were controlled by centre-left parties; the remaining ones were under the administration of centre parties or local lists.

Another aspect of local political competition that could be linked to the success of the M5S is the extent of alternation in municipal governments. Starting from the electoral cycle 1995-1999 one may see whether the composition of municipal governments has substantially changed or has remained the same. Using Valbruzzi's (2011) conceptualisation and operationalisation of alternation, I placed municipalities into one or the other of two groups: those in which the political orientation of the ruling majority changed at least once before the last election and those in which it did not. It may be expected that more political fluidity and instability at the local level will favour the emergence of a challenger, an anti-establishment actor like the M5S. Therefore

H4. Representation of the M5S is expected to be weaker in those municipalities characterised by a lack of political alternation.

Political stability can partly be the consequence of long-term 'political subcultures'. Trigilia (1986: 162) defined Italian regions with strong political subcultures as those characterised by 'the predominance of a particular political tradition, whose origins usually go back to the beginning of the century, and a complex of institutions (parties, interest groups, cultural and welfare structures) which derive from the same politico-ideological matrix'. In particular, two types of political subculture have been detected in Italy. The first one is the so-called 'red' subculture (Floridia, 2010), dominated by left-wing parties, which emerged in the central Italian regions, particularly in Tuscany, Emilia Romagna and Umbria (the so-called 'red belt'). The second one is the 'white' subculture (Baccetti and Messina, 2009) that was promoted and supported by Catholic organisations and by the Christian Democratic Party (DC) in the north-east of Italy, particularly in Veneto and Friuli-Venezia Giulia. Generally, it may be expected that in regions characterised by strong political subcultures, political parties that are linked to such subcultures are more resilient in the 
electoral competition at the local level. This may in turn have a limiting effect on the emergence and strengthening of challenging political forces like the M5S. Therefore,

H5. The M5S share of local representatives is, on average, smaller in regions characterised by the existence of strong political subcultures.

Yet, it should also be noted that in white regions the political dominance of the DC was abruptly interrupted in the 1990s, when the established party system was transformed as a result of changes in the international political system - such as the end of Communism in Eastern Europe and processes of Europeanisation (Golden 2004) - and by corruption scandals related to the so-called 'Tangentopoli' affair. The effects of such changes have been much less marked in the case of the main party of the left, the Communist Party, which, despite undergoing a process of ideological and organisational reform (Vampa, 2009), managed to survive a period of radical political change. Thus, whereas in the red regions we find organisational and electoral continuity in the dominance of centre-left parties, in the white regions changes in the political landscape have been so dramatic that they may have seriously undermined well-established political traditions. Indeed, although subcultures are well-rooted in society and are long-term phenomena that do not immediately disappear as a consequence of (mainly) exogenous shocks, they tend significantly to weaken or be transformed when the political offer radically changes. Therefore, a more refined sub-hypothesis is formulated:

H5a. The M5S share of local representatives is, on average, smaller in regions characterised by a red (i.e. centre-left) political subculture than in those that used to be dominated by the white (i.e. Christian Democratic) political subculture.

The final hypothesis to be tested is whether, at the local level, the phenomenon of protest politics embodied by the M5S is linked to what Putnam (1993) has called 'social capital' or 'civicness'. His study has suggested that central-northern Italian regions are characterised not only by higher levels of economic development but also by a more dynamic and integrated civil society than southern regions. Thus the concept of 'socio-economic development', which encompasses both the economic and social maturity of a political system, can be used to compare central-northern and southern Italian regions. So far the link between socio-economic development and protest politics has not been sufficiently 
investigated. It can be hypothesised that this factor has an effect on political participation and, consequently, on forms of representation. The question is whether in more economically and socially developed Italian regions the decline of partisan representation has been more evident and has been counterbalanced by the emergence of the M5S. If one assumes that the crisis of partisanship is linked to processes of modernisation and to the emergence of a more complex society, one less controllable by political elites due to citizens' increasing awareness, the following hypothesis may be tested:

H6. The M5S has obtained a larger share of representatives in the municipalities of centralnorthern Italy than in those of southern Italy.

Having presented the main hypotheses related to the political and socio-economic characteristics of municipalities, I turn in the next section to their testing.

\section{Testing the hypotheses}

Table 1 provides an overview of the share of seats won by the M5S in the different contexts described by the hypotheses presented above. It can be noted that, contrary to expectations, the M5S has been stronger in those municipalities in which the legacy of local lists is weaker (in this case I considered independent and politicised local lists together). At the same time, there has been no big increase in the percentage of M5S council seats when early elections have been called. On the other hand, it seems that the M5S has achieved better results in centre-left municipalities and in those characterised by high levels of political stability since the late 1990s. The combination of these two aspects, a centre-left political legacy and high stability, seems to lead to the most noticeable result of this table: the M5S has been considerably stronger in the municipalities of regions characterised by a red political subculture. Finally, differences between central-northern and southern Italian municipalities also seem to be quite strong, with the Movement obtaining, on average, a much larger share of representation in the former than in the latter.

[Table 1 about here]

A multivariate, linear regression model can be used to control for the existence of spurious associations existing among the independent variables and provide a more 
systematic analysis of the local contextual variables that have favoured the success of the M5S. The first set of independent variables measures the share of council seats won by independent and politicised local lists in the period preceding the one considered in this study (H1). Secondly, I have created two binary variables considering the ideological orientation of the incumbent administration (H2): municipalities previously ruled by centre-left or centreright coalitions (1) are compared to a reference category representing 'apolitical' or 'centrist' administrations (0). In the third place, a dichotomous variable is used to test $\mathrm{H} 3$ and see whether the success of the M5S has been stronger in municipalities that have experienced early elections (coded 1) than in other municipalities (coded 0). Another binary variable considers whether, since the late 1990s, a municipality has experienced alternation (0) or not (1) (H4). Additionally, the existence of red or white political subctultures is taken into account and municipalities belonging to each of the two 'macro-regions' are compared to those in the rest of Italy (H5). Finally, the effect of socio-economic development (H6) is assessed by the coefficient of a binary variable dividing the Italian territory into centralnorthern regions (coded 1) and southern regions (coded 0 ).

Two control variables have been added to the model. Since the dataset includes municipalities ranging from 15,000 to 2 million inhabitants, variation in their size should be taken into account. Indeed, some studies have suggested that the size of municipalities may affect the characteristics of local democracy and party politics (Dahl and Tufte, 1973; EnnserJedenastik and Hansen, 2013). In the multivariate analysis, 'population size' is a continuous variable measured in thousands of inhabitants. Moreover, the regression model includes a control variable, which takes into account whether the municipal election occurred before or after the 2013 general election $(0=$ before; $1=$ after). Indeed, success in the national political arena may have had a general positive effect on the visibility and, in turn, on the electoral performance of the Movement.

Table 2 shows the results of the OLS model. It can be noted that the only two hypotheses that are strongly supported by our empirical evidence are H2 and H6. Indeed, the 'early election' coefficient is statistically significant at the 0.05 level and suggests that, on average, the share of representation won by the M5S would increase by 2 percentage points if early elections were called, controlling for the other variables included in the model. Additionally, the average share of municipal seats won by the Movement is expected to increase by 3.3 percentage points in the more socio-economically developed regions of the 
country (centre-north), holding all the rest constant. In this case the coefficient is statistically significant at the 0.01 level.

In contrast, $\mathrm{H} 1$ is not confirmed and, in fact, there is a significant negative association between the strength of independent local lists in the previous election and the percentage of M5S representation. For each percentage increase in the share of seats of an independent local list, we would expect to see a 0.7 percentage point decrease in the reprsentation of the M5S, holding the other variables constant. This suggests that the 'civic project' promoted by the M5S cannot be directly linked to previous experiences of more traditional local lists. In the case of politicised lists the partial association is still negative but not statistically significant. It should also be emphasised that, in contrast to the M5S, local lists are much stronger in the south than in the north of the country. Generally, the fragmentation and weakening of cross-territorial party organisations has been more accentuated in the South and political representation has been increasingly 'outsourced' to local lists. Therefore, it seems that, unlike the M5S, the phenomenon of local lists is linked more strongly to what Floridia (2014) calls the 'micro-notabilato', which indicates the emergence of clientelistic practices and the increasing autonomy of local notables from national party organisations. The M5S and local lists are clearly two different phenomena.

The coefficients for $\mathrm{H} 4$ are both negative but not statistically significant at any conventional level, although the magnitude of the centre-right coefficient is larger than that of the centre-left one. The coefficient for H5 is not statistically significant either, meaning that lack of alternation per se does not explain variation in the success of M5S lists. Yet it is very noticeable that the coefficient for 'red political subculture' is positive and statistically significant at any conventional level, indicating that, keeping the other variables constant, the share of M5S representation is expected to be on average 3.7 percentage points larger in municipalities belonging to the so-called 'red belt' than in those belonging to other regions that are not characterised by specific subcultures. Overall, it seems that the effects of centreleft incumbency (H3a) and lack of alternation (H4) are 'absorbed' by the 'red subculture' variable (H5).This suggests that the M5S has been more successful in those local contexts in which a 'progressive' political tradition has been dominant over a long period of time.

On the other hand, no significant result is found for the white regions. This is quite puzzling, since the more fluid political situation in this area of the country after the collapse of the DC had already paved the way for the rise of the Northern League (Tambini, 2012) which, in the period of systemic political change (in some respects similar to the current one) 
at the beginning of the 1990s, was referred to by Diamanti (1993) as an 'entrepeneur of the crisis' (imprenditore della crisi). One would expect a similar local phenomenon to occur in the case of M5S today. Yet the absence of a significant partial effect in the regression model may be due to the fact that in the white regions, the M5S faces the strong competition of the Northern League, which, more than twenty years after its first successes, can rely on a wellestablished organisation and may therefore effectively compete with the Movement in attracting anti-establishment votes in the local arena.

[Table 2 about here]

Finally, it seems that local representation obtained by the Movemement has been greater since the 2013 general elections. Yet, as I show in the next section, the coefficient of this dummy variable merely shows a general, 'average' effect of the national success achieved by the Movement on the strength of its local representation in the following elections. In fact, when looking at disaggregated, municipal data, the connection between local and national political dimensions is much weaker than one might expect in the case of the M5S.

\section{The M5S: the discrepancy between strength of local representation and success in national elections}

The results obtained in the previous section only partly confirm the hypotheses listed in the section before that. This means that, locally, the M5S phenomenon cannot be directly associated with the, more traditional, process of formation of 'local' lists. Another interesting finding is that the M5S has emerged as an important competitor of centre-left political parties in the municipalities of the so-called 'red regions'. This in turn casts doubt on the idea that the Movement, at least at the grassroots level, is fully apolitical and unrelated to pre-existing ideological traditions.

Having analysed the factors that explain the success of the M5S in the municipal arena, an additional aspect that would be interesting to investigate is whether there is a real connection between its local and national electoral performances. We have already seen that, in general, the share of representation of the M5S in local elections rose significantly after its success in the 2013 general election. This, however, is an average score based on a dummy variable (pre-/post-2013), which does not say anything about the existence of a positive 
relationship between the strength of local representation and national election results within each individual municipality.

One may hypothesise that the link between local and national success is particularly strong for traditional parties, in which local and national organisational dimensions are vertically integrated and depend on each other. Therefore, the electoral success of the latter depends on the strength of the former and vice-versa. In contrast, the more 'fluid' nature of new, anti-establishment political forces may weaken the link, within them, between the local grassroots and the national leadership.

Given its origins and its internal rules, the M5S has been called a 'non-party' (non partito) (Fornaro, 2012). In this case, it would not be surprising to find an extreme version of the loosely integrated, 'stratarchic' organisation described by Carty (2004), in which local and national leaders and activists are weakly connected and, in some cases, are almost completely separated (Katz and Mair, 2009). Indeed, consistently with the idea of stratarchy, the national leadership can still control the selection of national representatives and define the national strategy of the party (Bordandini et al., 2008: 319), whereas local organisations are free to select local candidates and appeal to (and establish alliances with) sectors of society that are not usually targeted by national election campaigns. This may produce discrepancies and contradictions in the electoral successes and in the political nature of a force like the M5S and may even undermine its cohesiveness. Not surprisingly, since the success in the 2013 general election, numerous contrasts have emerged between local activists and the national leadership of Beppe Grillo and Gianroberto Casaleggio. This may be partly explained by the divergent electoral appeal of the M5S at different levels of government.

The results shown in figures 1,2 and 3 are very telling of the different degrees of electoral connection between local and national territorial dimensions across the three main Italian parties. Each figure assesses the correlation between the share of municipal representation controlled by a party and its results in national elections. The unit of analysis is the municipality. In this case I referred to the 2014 European election as the most recent, 'non-local' (one can also say 'state-wide') election. Figure 1 shows that in the case of the Democratic Party (PD) there is a strong, positive correlation between the local and national dimensions (correlation coefficient, $\mathrm{R}=0.7$ ). Therefore, the stronger the political representation of the PD in a municipality, the greater will be its electoral result in the same municipality on the occasion of a non-local contest like the European election. Despite its party structure having undergone significant organisational transformations in the direction of 
lower integration and 'density' (Pasquino, 2009), the PD can still be considered the most 'solid' Italian party (and this says a lot about the state of party-based representative democracy in Italy). It is therefore not surprising to find a clear connection between the local and national successes of the party.

[Figure 1 about here]

Figure 2 shows that the correlation between local representation and success in national elections is still positive but much weaker in the case of a party like Forza Italia (FI), the main centre-right political formation in Italy (correlation coefficient, $\mathrm{R}=0.2$ ). Indeed, the party has been said to display a 'business firm model of party organisation' (Hopkin and Paolucci, 1999), which is characterised by high electoral instability and inconsistencies across different territorial levels of government.

[Figure 2 about here]

Lastly, I consider the correlation between the local representation obtained by the M5S in the last five years and its results in the 2014 European election. In this case, association between the two variables is almost completely absent (correlation coefficient, $\mathrm{R}=0.02$ ). This means that, when we consider results in individual municipalities, there is no clear link between M5S success in municipal elections and support for this party in non-local elections.

[Figure 3 about here]

Interestingly, as we saw in the previous section, the M5S has higher levels of municipal representation in central-northern towns and in regions characterised by a centreleft political subculture (the red regions). On the other hand, as shown in Table 3, in national elections the M5S obtained better scores in less socio-economically developed regions (the South) and in those characterised by weaker political subcultures. This inconsistency poses a relevant question about the double identity of the movement. In local politics the M5S is a 'civic' force, responding to demands for transparency in public administration and for improvement of local services on the part of citizens living in the wealthiest and most 
socially integrated (and progressive) areas of the country. In national politics the M5S is instead a 'protest' movement, obtaining most of its support in those areas of the country in which economic conditions are worse, social fragmentation is more evident and the organisation of more traditional political parties is weaker.

\section{[Table 3 about here]}

The tension between civic party and protest party is evident in the contrasts between the national leadership (tending towards the 'protest' dimension) and local representatives of the party (tending towards the 'civic' dimension). For instance, recent controversies over the absence of internal democracy and the protest-oriented platform of the Movement at the national level are quite emblematic. It is significant that Federico Pizzarotti, a member of the M5S elected mayor of Parma in $2012,{ }^{2}$ has been among the most vocal opponents of the leadership of Grillo and Casaleggio.

\section{The 2015 election: a new cycle?}

This article has focused on the 2010-2014 period. The 2015 local elections, which took place in more than one hundred municipalities above 15,000 inhabitants, seem to have marked the beginning of a new phase of 'maturation' for the Movement. Table 4 shows that, on average, the M5S obtained $6.6 \%$ of the municipal seats being contested, joining, for the first time in local elections, FI in second place behind the centre-left PD (20.1\%). In a context of substantial strengthening of non-partisan local lists, which in 2015 won, on average, almost $50 \%$ of the municipal seats $(48.7 \%)$, the M5S is today the only 'state-wide' political force that is still expanding its local representation.

Additionally, it should be noted that, on this occasion, there has been less discrepancy between North and South in the average share of municipal seats obtained by the Movement. In fact, at the last election M5S mayors were elected in important municipalities of the South such as Quarto (in Campania), Porto Torres (in Sardinia), Augusta and Gela (in Sicily), where, as a consequence, the Movement obtained a large share of seats. In contrast with past local elections, these victories were also accompanied by consistently positive results in many other municipalities of the Mezzogiorno. At the same time, the M5S did not achieve particular successes in the red regions. Yet it should be stressed that only five major 
municipalities in Emilia Romagna, Tuscany and Umbria participated in this electoral round and, therefore, the sample might not be representative.

Generally, as the results of the 2015 regional elections also clearly show (Vampa, 2015), the M5S seems to have overcome some of its internal contradictions and is consolidating its role as an important political competitor not only at the national but also, and in a more territorially homogeneous way, at the regional and local levels.

[Table 4 about here]

\section{Conclusions}

This article has aimed to shed light on the 'local political ecology' of new parties' success. Adding the local dimension to the study of protest politics may therefore provide additional information on the challenges that anti-establishment parties face. Such challenges may not only derive from the dynamics of inter-party competition but also from vertical, crossterritorial dynamics that may affect the internal equilibria and the programmatic identity of newly formed political forces.

The case of the M5S is quite emblematic since it was initially created as a network of local associations, which sought to improve municipal administration, and became a national movement only at a later stage. The article has shown that, on average, the local success of the M5S has been more significant when early municipal elections have been called (due to the collapse of the incumbent local government) and in the more socio-economically developed areas of Italy. Surprisingly, despite its 'apolitical nature', the M5S has also achieved important local successes in those regions where a left-wing political tradition has been dominant for many years.

At the same time, it has been shown that, when considering disaggregated, townbased data on elections and representation, the link between the local and national success of the Movement is quite weak. Indeed, in the last 'state-wide' elections (the 2014 European election), the M5S achieved its best results in the poorer and more politically fragmented areas of the country. The inconsistences between the local and national dimensions may explain the tensions existing between different levels of the Movement's organisation. Yet the results of the 2015 local and regional elections seem to suggest that, after two years of 'adjustment' crisis, the M5S has entered a phase of 'maturation' and consolidation of its role as the main opposition party across the national territory. At the same time, it should be 
recalled that Italy is a well-known case of a highly fluid political system. It remains to be seen whether in the next few years new tensions and discrepancies will threaten the stability, and even the survival, of Beppe Grillo's party.

\section{Notes}

[1] The Movement had already participated in 2008 under the banner 'Amici di Beppe Grillo' but 'while some of these candidates did manage to get elected as councillors, none gained over 4 per cent' (Bartlett et al. 2013: 22). The organisational transition to the M5S started in 2009 and only in December 2009 were the main general rules of the movement (the so-called 'non-statute') published.

[2] Pizzarotti was, in 2012, the first member of the M5S to become mayor of a large town. He won the local election in Parma at the second round with more than $60 \%$ of the vote. Interestingly, the incumbent centre-right administration of this municipality had collapsed due to corruption scandals and this paved the way for the success of Beppe Grillo's movement.

\section{References}

Aars, J. and H. Ringkjøb. 2005. "Party Politicisation Reversed? Non-partisan alternatives in Norwegian Local Politics.” Scandinavian Political Studies 28(2): 161-181.

Amelina, A., D. D. Nergiz, T. Faist and N. G. Schiller, eds. 2012. Beyond Methodological Nationalism. Research Methodology for Cross-Border Studies. New York and Abingdon: Routledge.

Baccetti, C. And P. Messina, eds. 2009. L'eredità. Le subculture politiche della Toscana e del Veneto. Padova: Liviana.

Baldini, G. 2002. "The direct election of mayors: an assessment of the institutional reform following the Italian municipal elections of 2001". Journal of Modern Italian Studies 7(3): 364-379.

Bartlett, J., C. Froio, M. Littler \& D. McDonnel. 2013. "New Political Actors in Europe: Beppe Grillo and the M5S". Report, DEMOS.

Bartolini, S. 2004. "Old and New Peripheries." In Restructuring Territoriality. Europe and the United States compared edited by C. Ansell and G. di Palma, 19-44. Cambridge: Cambridge University Press.

Bartolini, S. 2005. Restructuring Europe. Oxford: Oxford University Press. 
Biorcio, R. 2014. "The reasons for the success and transformations of the 5 Star Movement." Contemporary Italian Politics 6(1): 37-53.

Bordignon, F. and L. Ceccarini. 2013. "Five Stars and a Cricket. Beppe Grillo Shakes Italian Politics." South European Society and Politics 18(4): 427-449.

Caramani, D. 2004. The Nationalization of Politics. The Formation of National Electorates and Party Systems in Western Europe. Cambridge: Cambridge University Press.

Carty, R. K. and M. Eagles. 1998. 'The political ecology of local party organization: the case of Canada', Political Geography 17(5): 589-609.

Carty, R. K. 2004. "Parties as Franchise Systems: The Stratarchical Organizational Imperative" Party Politics 10(1): 5-24.

Conti, N. and V. Memoli. 2015. "The Emergence of a New Party in the Italian Party System: Rise and Fortunes of the 5 Star Movement.” West European Politics 38(5): 516-534.

Dahl, R. A. and E. R. Tufte. 1973. Size and democracy. Stanford: Stanford University Press.

De Lucia, F. 2012. "Il successo del Movimento 5 Stelle." in Le Elezioni Comunali 2012 edited by L. De Sio and A. Paparo, 65-67. Roma: CISE.

Detterbeck, K. 2005. “Cartel Parties in Western Europe?” Party Politics 11(2): 173-191.

De Winter, L. and H. Türsan, eds. 1998. Regionalist Parties in Western Europe. London and New York: Routledge.

Diamanti, I. 1993. "La Lega imprenditore politico della crisi. Origine, crescita e successo delle leghe autonomiste in Italia." Meridiana, 16: 99-133.

Ennser-Jedenastik, L. and M. E. Hansen. 2013. 'The Contingent Nature of Local Party System Nationalisation: The Case of Austria 1985-2009." Local Government Studies 39(6): 777-791.

Floridia, A. 2010. "I rapporti cambiano, i valori restano? Una ricerca quantitativa e qualitativa sulla cultura politica in Toscana." Paper presented at the XXIV SISP conference, Venice, 16-18 September.

Floridia, Antonio. 2014. "Il voto amministrativo nel Centro-sud: 1'apoteosi del micronotabilato." In L'Italia e L'Europa al bivio delle riforme: Le elezioni europee $e$ amministrative del 24 maggio 2014, edited by Marco Valbruzzi and Rinaldo Vignati, 433447. Bologna: Istituto Carlo Cattaneo.

Fornaro, F. 2012. “Un non-partito: il Movimento 5-Stelle.” Il Mulino (la rivista 2: 253-262.

Golden, M. 2004. "International Economic Sources of Regime change." Comparative Political Studies, 37(10): 1238-1274. 
Hartleb, F. 2013. “Anti-elitist cyber-parties?” Journal of Public Affairs 13(4): 355-369.

Hepburn, E. 2010. Using Europe: Territorial party strategies in a multi-level system. Manchester: Manchester University Press.

Hino, A. 2012. New Challenger Parties in Western Europe. A comparative analysis. London and New York: Routledge.

Holtmann, E. 2008. "Local lists in Europe." In Farewell to the Party Model Independent Local Lists in East and West European Countries edited by M. Reiser and E. Holtmann, 1119. Wiesbaden: VS Verlag für Sozialwissenschaft,.

Hooghe, L., G. Marks and A.H. Schakel. 2010. The Rise of Regional Authority: a comparative study of 42 democracies. Abingdon and New York: Routledge.

Hopkin, J. and C. Paolucci. 1999. "The business firm model of party organization: Cases from Spain and Italy." European Journal of Political Research 35(3): 307-339.

Jeffery, C. 2008. "The challenge of territorial politics." Policy and Politics 36(4): 545-557.

Jeffery, C. and D. Wincott. 2010. "The challenge of territorial politics: Beyond Methodological Nationalism." In New Directions in Political Science: Responding to the Challenges of an Interdependent World edited by C. Hay, 167-188. Basignstoke: Palgrave Macmillan.

John, P. 2001. Local Governance in Western Europe. London, Thousand Oaks, New Delhi: Sage Publications.

Katz, R. S. and P. Mair. 1995. "Changing Models of Party Organization and Party Democracy: the Emergence of the Cartel Party" Party Politics, 1(1): 5-28.

Katz, R. S. and P. Mair. 2009. "The Cartel Party Thesis: A Restatement." Perspectives on Politics, 7: 753-766.

Lanzone, M. E. and F. Tronconi. 2015. "Between Blog, Social Networks and Territory: Activists and Grassroots Organisation". In Beppe Grillo's Five Stars Movement: Organisation, Communication and Idelogy edited by F. Tronconi, 53-74. Surrey and Burlington: Ashgate.

Loughlin, J., ed. 2001. Subnational Democracy in the European Union: Challenges and Opportunities, Oxford and New York: Oxford University Press.

Matthijs, M. 2014. "Mediterranean Blues: the Crisis in Southern Europe." Journal of Democracy 25(1): 101-115.

Müller, W. C. and K. Strøm, eds. 1999. Policy, Office, or Votes? How Political Parties in Western Europe Make Hard Decisions. New York, Melbourne, Madrid, Cape Town, Singapore, São Paulo: Cambridge University Press. 
Natale, P. 2014. "The birth, early history and explosive growth of the Five Star Movement." Contemporary Italian Politics 6(1): 16-36.

Palermo, F. and A. Wilson. 2014. "The multilevel dynamics of state decentralization in Italy." Comparative European Politics 12(4-5): 510-530.

Pasquino, G., ed. 2009. Il Partito Democratico: Elezione del Segretario, Organizzazione e Potere, Bologna: Bononia University Press.

Pritoni, A. 2014. "Le comunali in Piemonte, Lombardia, Liguria e Veneto: c'era una volta il Nord (di destra)." In L'Italia e L'Europa al bivio delle riforme: Le elezioni europee e amministrative del 24 maggio 2014 edited by M. Valbruzzi and R. Vignati 384-401. Bologna: Istituto Carlo Cattaneo.

Putnam, R. D. 1993. Making Democracy Work. Civic Traditions in Modern Italy. Princeton: Princeton University Press.

Reiser, M. and E. Holtmann, eds. 2008. Farewell to the Party Model: Independent Local Lists in East and West European Countries. Wiesbaden: VS Verlag für Sozialwissenschaft.

Tambini, D. 2001. Nationalism in Italian Politics: The Stories of the Northern League, 19802000, New York: Routledge.

Trigilia, C. 1986 "Small-firm development and political subcultures in Italy." European Sociological Review, 2(3): 161-175.

Tronconi, F. (2015). Beppe Grillo's Five Stars Movement: Organisation, Communication and Idelogy. Surrey and Burlington: Ashgate.

Turner, E. 2013. "The Grillini in Italy: New Horizons for Internet-based Mobilization and Participation." Social Movement Studies: Journal of Social, Cultural and Political Protest, 12(2): 214-220.

Valbruzzi, M. 2011. "Cosa è 'alternanza' in politica e come va studiata". Paper presented at the XXV SISP Conference, Palermo.

Vampa, D. 2009. "The Death of Social Democracy: The Case of the Italian Democratic Party." Bulletin of Italian Politics 1(2): 347-370.

Vampa, D. 2015. "The 2015 Regional Election: Fragmentation and Crisis of Subnational Representative Democracy." Regional \& Federal Studies, DOI: 10.1080/13597566.2015.1074073.

Ventura, S. 2013. "Leaders and parties after the Italian elections." Contemporary Italian Politics 5(2): 179-195. 
Wimmer, A. \& Glick Schiller N. 2002. "Methodological nationalism and beyond: nationstate building, migration and the social sciences." Global Networks 2(4): 301-334 
Table 1. Mapping the strength of M5S representation in different contexts (average percentage of municipal council seats)

\begin{tabular}{|c|c|}
\hline Independent variables & $\%$ of seats \\
\hline Strength of local lists in 2005-2009 & \\
\hline Strong local lists (>average) & 3.0 \\
\hline Other (<average) & 5.5 \\
\hline Early elections & \\
\hline Yes & 5.0 \\
\hline No & 4.4 \\
\hline Incumbent administration & \\
\hline Centre left & 5.8 \\
\hline Centre right & 3.4 \\
\hline Other & 2.9 \\
\hline Alternation since late 1990s & \\
\hline Yes & 3.4 \\
\hline No & 5.8 \\
\hline Political subculture & \\
\hline No subculture & 3.0 \\
\hline Red & 10.4 \\
\hline White & 5.5 \\
\hline North-South divide & \\
\hline Central-northern regions & 6.9 \\
\hline Southern regions & 2.0 \\
\hline
\end{tabular}


Table 2. The determinants of M5S success in municipal representative institutions (dependent variable: percentage of coucil seats won by the M5S)

\begin{tabular}{|l|l|}
\hline $\begin{array}{l}\text { H1. Strength of local lists' representation in } \\
\text { previous council }\end{array}$ & Coefficient \\
\hline 1. Independent local list (t-1) & $-0.7^{* *}(0.03)$ \\
\hline 2. Politicised local list (t-1) & $-0.025(0.02)$ \\
\hline H2. Early election & $2 * *(0.76)$ \\
\hline $\begin{array}{l}\text { H3. Political orientation of previous } \\
\text { administration }\end{array}$ & \\
\hline \multicolumn{1}{|c|}{ Centre-left (t-1) } & $-1.1(1.5)$ \\
\hline 2. Centre-right (t-1) & $-2.27(1.49)$ \\
\hline H4. Lack of alternation & $0.3(0.6)$ \\
\hline H5. Political subculture & \\
\hline \multicolumn{1}{|c|}{ Red political subculture } & $3.5^{* * *(1)}$ \\
\hline 2. White political subculture & $0.8(1.2)$ \\
\hline H6. Central-northern Italy & $3.3^{* * *(0.8)}$ \\
\hline Population size & $0.002(0.002)$ \\
\hline Post 2013 general election & $4.2^{* * *(0.6)}$ \\
\hline Constant & $1.8(1.7)$ \\
\hline Adjusted R-squared & 0.19 \\
\hline Number of observations & 671 \\
\hline
\end{tabular}

$* \mathrm{p}<0.1 ; * * \mathrm{p}<0.05 ; * * * \mathrm{p}<0.01$. OLS model, standard errors in brackets.

Table 3. The strength of M5S local representation and its performance in the 2014 European election. Comparing different areas of the country (higher scores in bold).

\begin{tabular}{|l|r|r|r|r|r|}
\hline & \multicolumn{2}{|c|}{ North/South } & \multicolumn{2}{|c|}{ Political Subcultures } \\
\hline & North & South & Red & White & $\begin{array}{r}\text { No } \\
\text { subculture }\end{array}$ \\
\hline Local representation (average \%) & $\mathbf{6 . 9}$ & 2.0 & $\mathbf{1 0 . 4}$ & 5.5 & 3.0 \\
\hline Votes in European election (average \%) & 19.2 & $\mathbf{2 5 . 7}$ & 18.2 & 19.6 & $\mathbf{2 3 . 6}$ \\
\hline
\end{tabular}


Table 4. The share of municipal seats won by the M5S and other political forces in the 2015 election.

\begin{tabular}{|l|r|r|r|r|r|r|}
\hline & \multicolumn{2}{|l|}{$\begin{array}{l}\text { North/South } \\
\text { (average \% of seats) }\end{array}$} & \multicolumn{3}{l|}{$\begin{array}{l}\text { Political subcultures } \\
\text { (average \% of seats) }\end{array}$} & $\begin{array}{l}\text { Average \% of } \\
\text { seats in all } \\
\text { municipalities }\end{array}$ \\
\hline & \multicolumn{1}{|l|}{ North } & \multicolumn{1}{l|}{ South } & \multicolumn{1}{l|}{ Red } & \multicolumn{1}{l}{ White } & No subculture & \\
\hline M5S & 7.7 & 6.0 & 5.8 & 4.8 & 6.7 & 6.6 \\
\hline PD & 25.5 & 17.5 & 29.4 & 17.4 & 19.8 & 20.1 \\
\hline FI & 8.4 & 5.9 & 7.5 & 5.7 & 6.6 & 6.6 \\
\hline Local lists & 31.6 & 57.0 & 38.1 & 46.9 & 49.3 & 48.7 \\
\hline Other parties & 34.4 & 19.7 & 29.9 & 25.0 & 24.2 & 24.5 \\
\hline
\end{tabular}


Figure 1. Correlation between strength of PD local representation and PD results in the last state-wide election (2014 EU election). $\mathrm{R}=0.7$

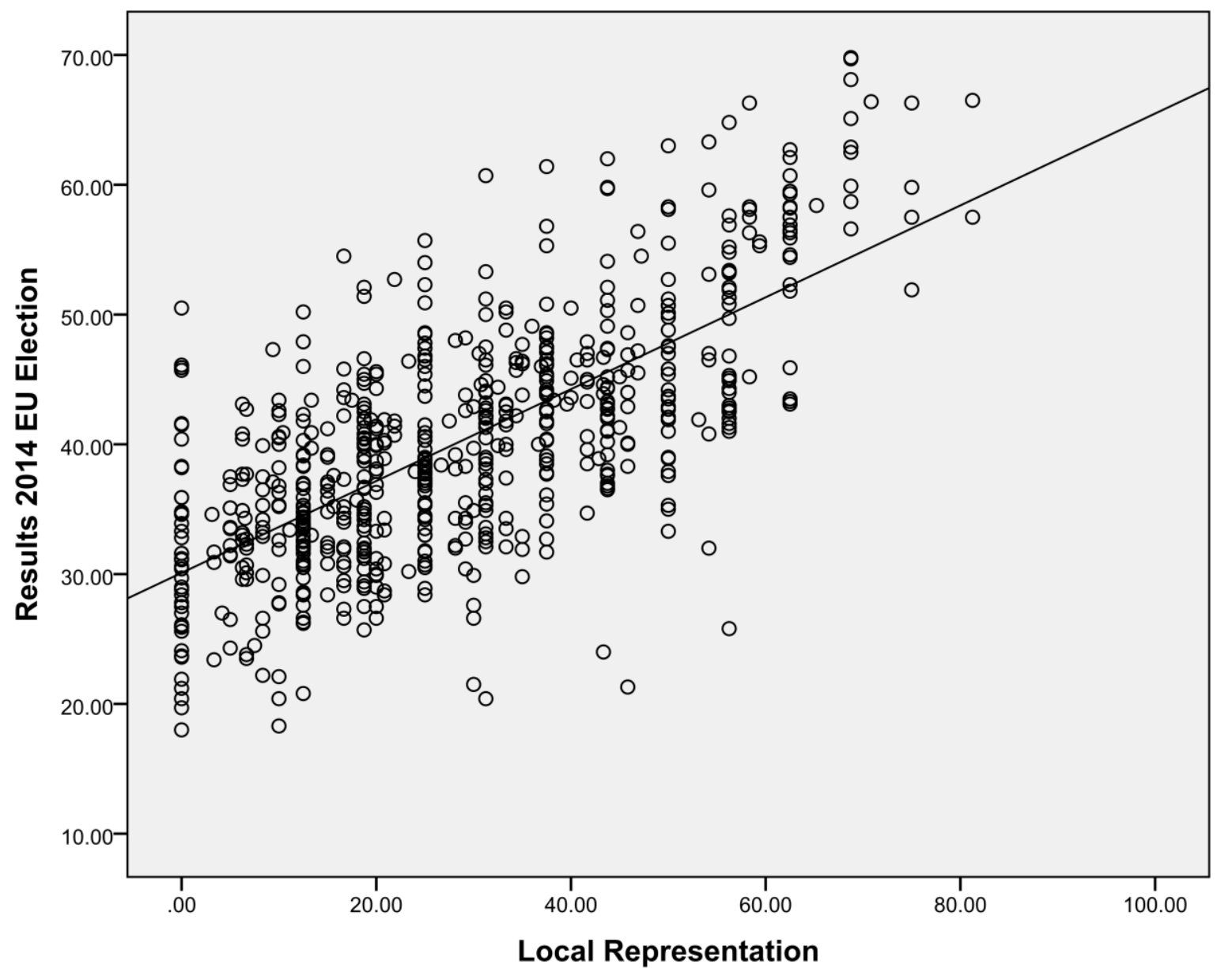


Figure 2. Correlation between strength of FI/PdL local representation and FI results in the last state-wide election (2014 EU election). $\mathrm{R}=0.2$

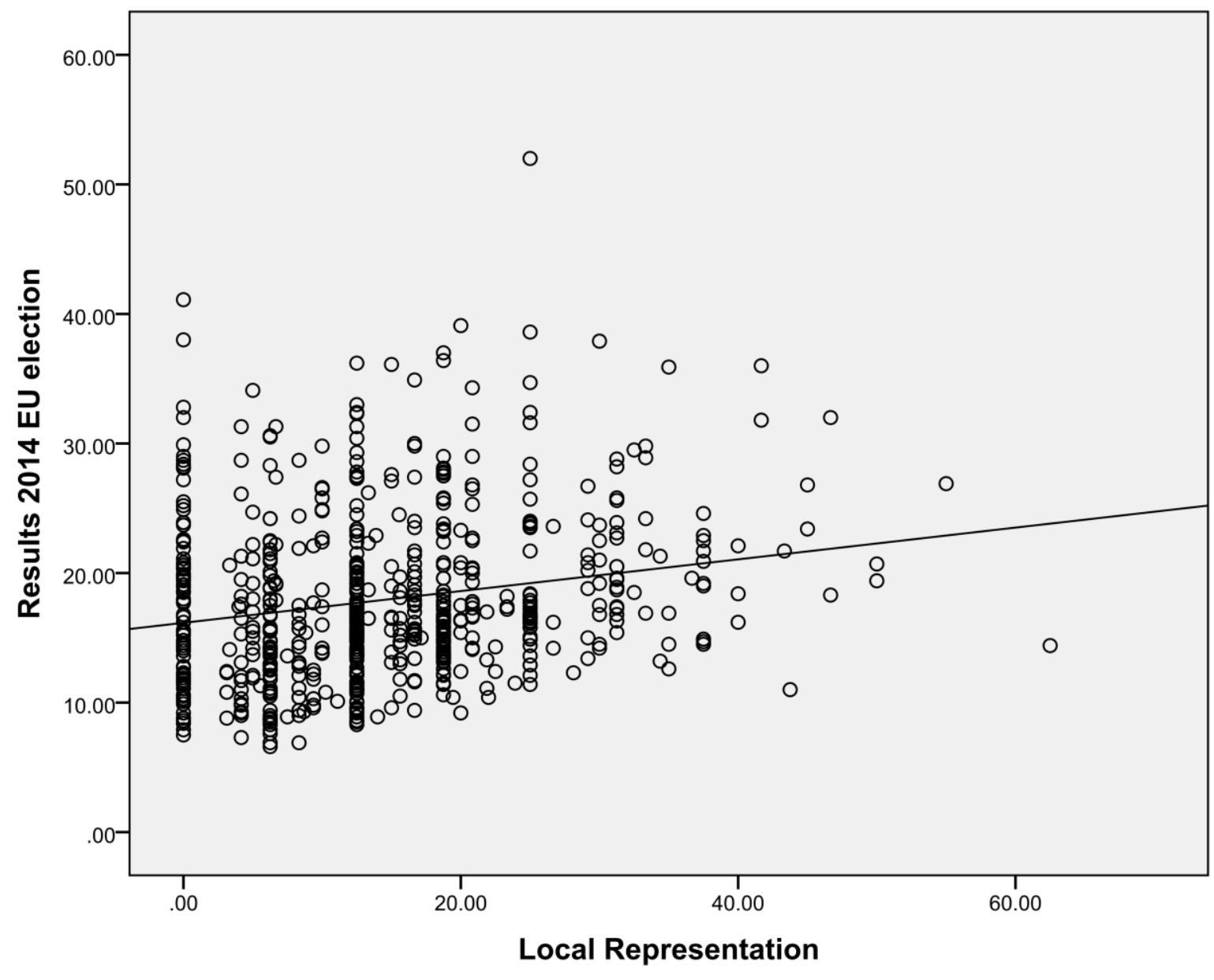


Figure 3. Correlation between strength of M5S local representation and M5S results in the last state-wide election (2014 EU election). $\mathrm{R}=0.02$

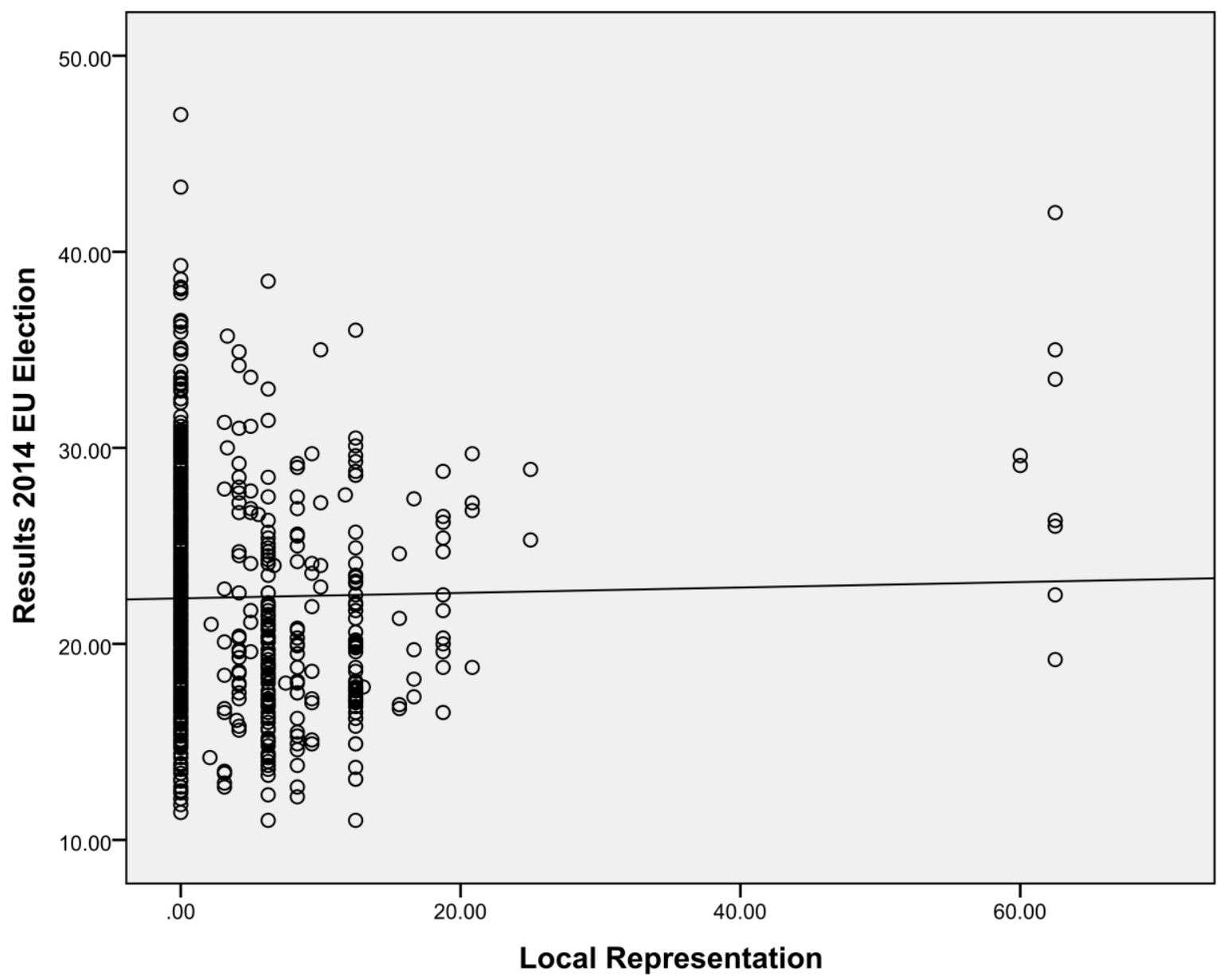

